\title{
A hepatitis C-vírus (HCV) három évtizede a felfedezéstől a globális elimináció lehetőségéig: a transzlációs kutatás sikere
}

\author{
Pár Alajos dr. - Pár Gabriella dr. \\ Pécsi Tudományegyetem, Általános Orvostudományi Kar, Klinikai Központ, I. Belgyógyászati Klinika, Pécs
}

Több mint 25 évvel a hepatitis C-vírus felfedezése után a >90\%-os tartós vírusmentességet okozó direkt ható antivirális szerek kifejlesztésével megnyílt az elvi lehetősége a hepatitis C-vírus regionális, hosszú távon pedig globális eliminációjának. Mindez az alap- és a klinikai transzlációs kutatások sikerének tekinthető. Kihívások azonban maradtak, úgy mint a még fel nem ismert vírushordozók nagy száma, a készítmények magas ára miatt a terápiához való hozzáférés korlátozottsága és a terápiarezisztens variánsok kezelése. Probléma a vakcináció hiánya is. Az Egészségügyi Világszervezet (WHO) 2016-ban célul tüzte ki a vírushepatitisek globális eradikációját 2030-ra, és ehhez irányelveket fogalmazott meg a nemzeti szűrőprogramok készítői számára. Ebben fontos szerepet kap a magas kockázati populációkban a fertőzöttek felderítése és kezelése, ezáltal a fertőzés terjedésének meggátlása, továbbá a törekvés a reinfekciók megelőzésére. A dolgozat áttekintést ad a hepatitis C-vírus három évtizedes történetéről, a felfedezéstől napjainkig, érintve a virológia, az epidemiológia, a patogenezis, a diagnosztika, a szűrés és a terápia kérdéseit.

Orv Hetil. 2018; 159(12): 455-465.

Kulcsszavak: hepatitis C-vírus, virológia, epidemiológia, patogenezis, diagnózis, terápia, szűrés, prevenció, elimináció

\section{Three decades of the hepatitis $\mathrm{C}$ virus from the discovery to the potential global elimination: the success of translational researches}

\begin{abstract}
More than 25 years after the discovery of hepatitis $\mathrm{C}$ virus, the development of the direct acting antivirals can lead to the regional or long-term global elimination of the virus with over $90 \%$ efficacy. This is the success of basic and clinical translational research. Yet, some unsolved challanges remain, such as the great number of unidentified patients who are not aware of their condition, the limited access to the therapy due to the high prices of the drugs, and the treatment of resistance-associated variants. In addition, the lack of vaccine is also an obstacle. In 2016, the World Health Organization (WHO) developed the first global health sector strategy for the elimination of viral hepatitis by 2030. Its evidence-based guidelines are primarily targeted at the national hepatitis programme managers who are responsible for the national testing and treatment plans. According to these recommendations, it is of basic importance to perform focused risk-based testing in higher-risk populations and after diagnosis to start treatment as "cure as prevention", furthermore, to limit the risk of reinfection. We review the events of the HCV story from the discovery to these days, including virology, epidemiology, pathogenesis, diagnosis and therapy.
\end{abstract}

Keywords: hepatitis C virus, virology, epidemiology, pathogenesis, diagnosis, screening, treatment, prevention, elimination

Pár A, Pár G. [Three decades of the hepatitis C virus from the discovery to the potential global elimination: the success of translational researches]. Orv Hetil. 2018; 159(12): 455-465.

(Beérkezett: 2017. november 19.; elfogadva: 2018. január 2.)

Semmelweis Ignác születésének 200. évfordulója évében a Szerkesztőség felkérésére készített tanulmány. 


\section{Rövidítések}

APRI score $=($ aspartate aminotransferase platelet ratio index $)$ GOT/thrombocyta hányados; $\mathrm{CP}=$ Child-Pugh; DAA $=($ direct-acting antiviral) direkt ható antivirális szer; CTLA4 $=$ cytotoxicus T-lymphocyta-asszociált antigén- $4 ; \mathrm{DNS}=$ dezoxiribonukleinsav; EASL $=($ European Association for the Study of the Liver) Európai Májkutatási Társaság; ELF $=($ Enhanced Liver Fibrosis test) fokozott májfibrosis teszt; ELISA = (enzymlinked immunosorbent assay) enzimkötött immunoszorbens vizsgálat; $\mathrm{ER}=$ endoplasmaticus reticulum; $\mathrm{F}$ = fibrosis; $\mathrm{GGT}$ = gamma-glutamiltranszferáz; GOT = glutaminsav-oxálecetsavtranszamináz; GPT = glutaminsav-piroszőlősav-transzamináz; $\mathrm{GT}=$ genotípus HAV $=$ hepatitis A-vírus $\mathrm{HBV}=$ hepatitis $\mathrm{B}$ vírus, $\mathrm{HCC}=$ hepatocellularis carcinoma; $\mathrm{HCV}=$ hepatitis $\mathrm{C}$ vírus; HLA = humán leukocytaantigén; IFN = interferon; IRES $=($ internal ribosome entry site $)$ belső riboszómabelépési hely; $\mathrm{kb}=$ kilobázis; KIR = killer sejt immunglobulinszerü receptor; $\mathrm{LDL}=$ (low-density lipoprotein) alacsony sürüségú lipoprotein; MELD = (Model for End-stage Liver Disease $)$ végstádiumú májbetegség modellje; MHC = (major histocompatibility complex) fó hisztokompatibilitási rendszer; $\mathrm{miR}=$ mikro-RNS; $\mathrm{MSM}=($ men sex with men $)$ homoszexuális férfi; NA = nukleotidanalóg; NAFLD = (non-alcoholic fatty liver disease $)$ nem alkoholos zsírmáj; NANB = (non-A, non-B) nem $A$, nem B; $\mathrm{NK}=$ (natural killer) természetes ölő; $\mathrm{NS}=$ nem strukturális; $\mathrm{PCR}=$ polimeráz-láncreakció $; \mathrm{PDI}=($ programmed cell death 1 receptor) programozott sejthalál-1-receptor; peg-IFN = pegilált interferon; $\mathrm{PI}=$ proteázgátló; $\mathrm{R}=$ ritonavir; $\mathrm{RAV}=$ rezisztenciaasszociált variáns; $\mathrm{RBV}=$ ribavirin; $\mathrm{RNS}=$ ribonukleinsav; $\mathrm{SNP}=$ ( single nucleotide polymorphism $)$ egy nukleotidot érintő polimorfizmus; SR-BI = B csoportú l-es típusú scavenger receptor; $\mathrm{SVR}=$ (sustained virological response) tartós virológiai válasz; TIMI $=\mathrm{T}$-sejt-immunglobulin-mucin-receptor- $1 ; \mathrm{TNF}=$ tumornekrózis-faktor; $\mathrm{VLDL}=($ very low density lipoprotein) nagyon alacsony sűrűségű lipoprotein; WHO = (World Health Organization) Egészségügyi Világszervezet

A hepatitis C-vírus (HCV) története a kórokozó felfedezésétől a direkt ható antivirális szerek (DAA) kifejlesztéséig a sikeres transzlációs kutatások példája. A HCV-fertôzés gyógyíthatóvá vált, és megteremtődött a lehetősége a vírus globális eliminálásának. Ezen túlmenően a HCV molekuláris biológiájával kapcsolatos ismeretek hozzájárulhatnak más vírusok, például a Zika-vírus, illetve a nyugat-nílusi lázat vagy a dengue-lázat okozó vírusok elleni stratégiák kidolgozásához is. Ugyanakkor még számos kihívás további erőfeszítést igényel: fontos a nagyszámú, még fel nem ismert vírushordozó felkutatása szürôprogramokkal, majd azt követően a fertözöttek kezelése a DAA-kombinációkkal. Probléma a terápiához való hozzáférés a készítmények magas ára miatt, megoldandó a DAA-rezisztens vírusvariánsok kezelése is, végül kérdés, hogy egyáltalán lehet-e szó globális eradikációról vakcináció nélkül [1,2]. Az Orvosi Hetilapban az elmúlt években több dolgozat is foglalkozott a HCV kérdéseivel [3-8], mégis - a terápia új korszakába lépve és az Egészségügyi Világszervezet (WHO) 2016. évi ajánlásait is figyelembe véve $[9,10]$ - érdemesnek tartottuk a HCV három évtizedének átte- kintését a kezdetektốl napjainkig a virológia, az epidemiológia, a patogenezis, a diagnosztika és a terápia terén elért haladást illetően.

\section{A felfedezés és a vírus}

Az 1970-es évek közepén, miután megoldódott mind a hepatitis $B$-virus (HBV), mind a hepatitis A-virus (HAV) szerológiai diagnosztikája, kiderült, hogy a poszttranszfúziós hepatitisek nagy részében sem HAV-, sem HBVmarkerek nem találhatók. Ez vezetett a non- $A$, non- $B$ (NANB) hepatitis elnevezéshez [11]. A feltételezett NANB-kórokozóról csimpánzkísérletben igazolták, hogy fertőző ágens [12], Schaff és mtsai pedig elektronmikroszkópos vizsgálatokkal azt mutatták ki, hogy a NANB-fertózött állatok májában jellegzetes endoplazmatikus eltérések és „zárványok" észlelhetők, ami a vírusszaporodás helyére utalt [13]. Több mint egy évtizeden át NANB-hepatitisről beszéltünk. Az első feltételezéstől számítva 15 év elteltével, 1989-ben teljesen új módszerrel, molekuláris biológiai és állatkísérletes technikák kombinálásával, fertőzött csimpánzokból klónozták a patogént, amelyet hepatitis C-pirusnak (HCV) neveztek el [14].

\section{Virológia}

A HCV-re jellemző a nukleokapszidban a 9,6 kilobázis (kb) hosszú, pozitív polarizációjú egyfonalú RNS-genom, 40-80 nm átmérőjü, lipidburokkal fedett Hepacivirus a Flaviviridae családban, rokonságban a Zika-vírussal, illetve a sárgalázat, a nyugat-nílusi lázat és a dengue-lázat okozó vírusokkal. Nagy genetikai diverzitása a vírus és az ember közötti hosszú evolúciós társulásra utal [15]. A HCV-nek 7 genotípusa (GT) és 67 altípusa ismert, ezek megoszlása földrajzi régiónként változik. Globálisan a HCVl-GT 46\%-ban, a GT3 22-30\%-ban, míg a GT4 13\%-ban fordul elő. A HCVla Észak-Európában, az lb Dél-Európában, a 2c Szardínián gyakori. Európában $90 \%$ a GTl, -2 és -3 , míg a GTl, -2 , - 4 és -5 Afrikában endémiás, a GT3 és -4 pedig Ázsiában fejlődött ki $[2,15,16]$.

A HCV a vérben különböző genomok keverékeként kering, ezek a kvázispeciesek. Keletkezésük a HCV gyors replikációjával, az RNS-polimeráz hibás (error-prone) múködésével és a HCV nagy mutációs rátájával kapcsolatos $[15,16]$.

A víruspartikulumban a HCV-RNS a nukleokapszidba (core protein) beágyazva található. Ezt kettős rétegú $l i$ pidburok veszi körül, amelyben az E1- és az E2-glikoprotein van lehorgonyozva; ezek a vírus sejtbelépésében játszanak szerepet. Amerikai szerzőkkel Schaff és mtsai elsőként igazolták, hogy a core protein szerepet játszik a HCV okozta steatosisban és onkogenezisben [17].

A HCV a gazdasejtek felszíni receptoraihoz kötődve klatrin mediálta endocytosissal lép be a sejtbe. A gazdasejt receptorait a sejtkapcsoló (tight-junction) fehérjék (klau- 
din-1, okkludin), a scavenger receptor-Bl (SR-Bl), az LDL-receptor és a CD81-es molekula képviseli. A cytoplasmában előbb a nukleoprotein, majd az RNS kiszabadulása után az RNS átíródása és replikációja következik. $\mathrm{Az}$ endoplasmaticus reticulumban (ER) az RNS-ról 3000 aminosavból álló polipeptid képződik, ezt gazdai és virális proteázok 3 strukturális és 7 nem strukturális (NS) proteinre hasítják le.

Strukturális proteinek: a HCV core (nukleokapszid), az E1- és E2-burok-glikoprotein; nem strukturális proteinek: p7-viroporin, NS2-cisztein-autoproteáz, NS3-helikáz, NS3/4A-szerin-proteáz, NS4B integrált membránprotein, NS5A replikációskomplex-protein és NS5B RNS-dependens RNS-polimeráz.

Az ER-ből származó lipidmembránnal borított HCV lipoviropartikula formájában a VLDL szekretoros útja révén jut ki a sejtből. A HCV a hepatocyták és a mononukleáris sejtek cytoplasmájában replikálódik: fertőzött sejtenként naponta 50 , összesen mintegy $10^{7}$ virion képződik [15, 16, 18].

Az 1. ábra a HCV életciklusát és a DAA-k támadáspontjait szemlélteti.

\section{Epidemiológia}

Globálisan az anti-HCV-pozivitás előfordulása 1,6\% (1,3-2,1\%), ami 115 (92-149) millió HCV-fertőzött egyént jelent. A HCV-viraemiások aránya $1,0 \%(0,8-$ 1,14\%), ez 71 (62-79) millió HCV-RNS-hordozónak felel meg $[2,15,16]$.
A HCV-prevalencia jelentős földrajzi különbségeket mutat. Elsősorban iatrogén infekciók következtében magas (>5\%) az anti-HCV-pozitivitás aránya Kamerun, Gabon, Grúzia, Mongólia, Nigéria és Üzbegisztán területén. Egyiptomban a schistosomiasis injekciós terápiája kapcsán a populáció $>20 \%$-a fertőződött. Az anti-HCVelőfordulás 3,5\% felett van Közép- és Kelet-Ázsia, ÉszakAfrika és a Közép-Kelet, míg 1,5-3,5\% közötti DélkeletÁzsia, Afrika, Latin-Amerika, Közép- és Kelet-Európa országaiban, és <1,5\% Óceánia, Észak-Amerika, a trópusi Latin-Amerika és Nyugat-Európa területén; Skandináviában $0,3 \%$ a prevalencia.

A világon az összes viraemiás (HCV-RNS-pozitív) eset felét Kína, Pakisztán, India, Egyiptom és Oroszország adja $[2,15,16]$.

Hazánkban 1996. évi adatok szerint $0,7 \%$ az antiHCV-prevalencia [19]. Gervain 2014-es vizsgálatai $0,8 \%$ anti-HCV-szeropozitivitás mellett $78 \%$-os viraemiás arányt igazoltak, így 0,62\%, vagyis 60760 lehet ma Magyarországon a HCV-RNS-hordozók száma. A hazai GT-megoszlás 2000 és 2017 között: la: 5,6\%; lb: 84,6\%; la + 1b: 5,87\%; 3: 1,39\%; 4: 0,07\%, és néhány \% kevert genotípus: la, lb, 2, 4 (Gervain személyes közlése, megjelenés alatt).

A 2. ábra a viraemiás HCV-fertőzés globális előfordulását mutatja $[2,16]$.

A HCV-infekció fó kockázati tényezôit az ipari államokban az 1992 előtti vértranszfúziók és plazmakészítmények, a kábítószer-használat és bizonyos szexuális magatartás (férfihomoszexualitás, „men sex with men” = MSM), a fejlődő országokban pedig a nem megfelelően

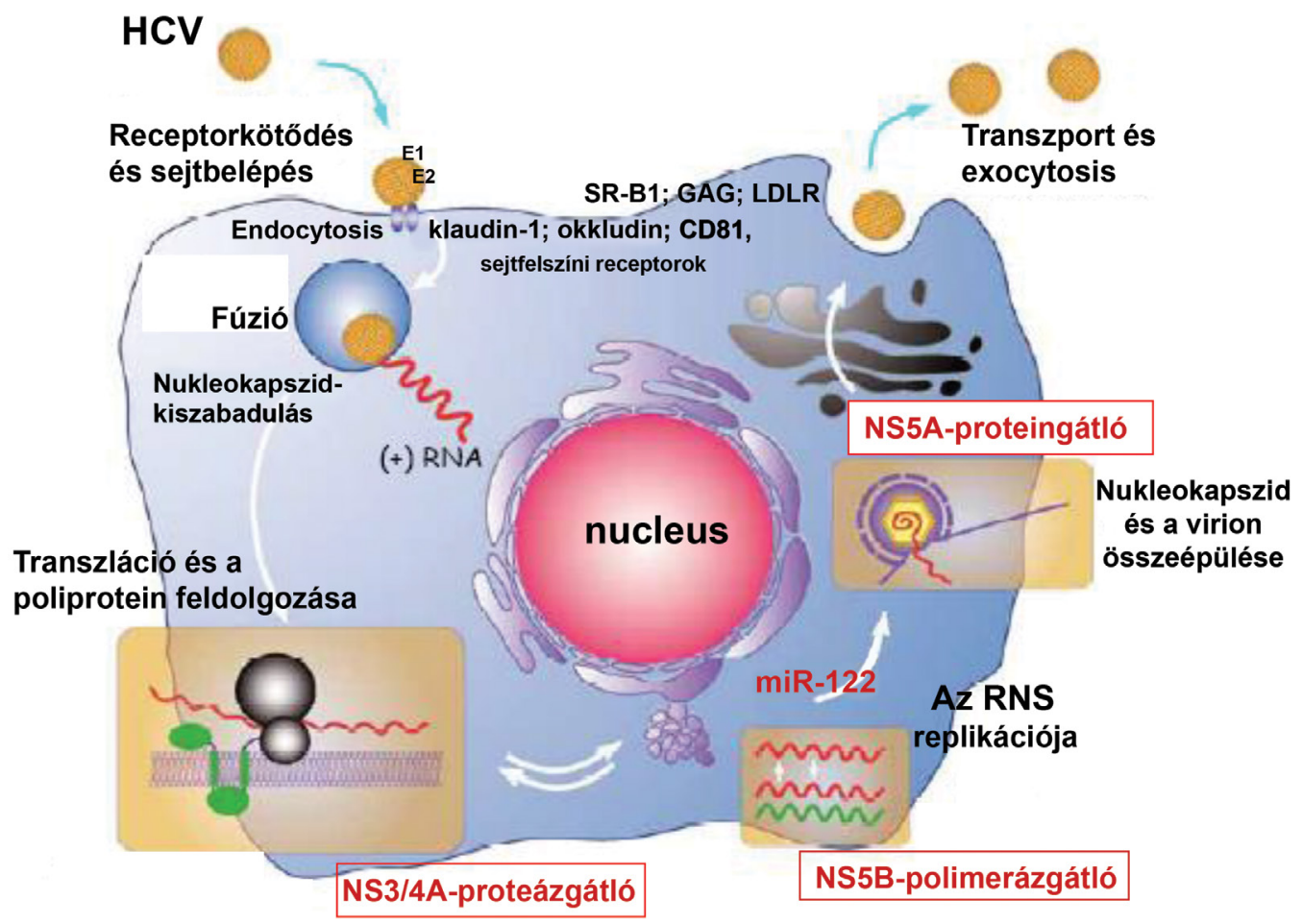

1. ábra

| A HCV életciklusa és a direkt ható antivirális (DAA-) kezelés támadáspontjai 


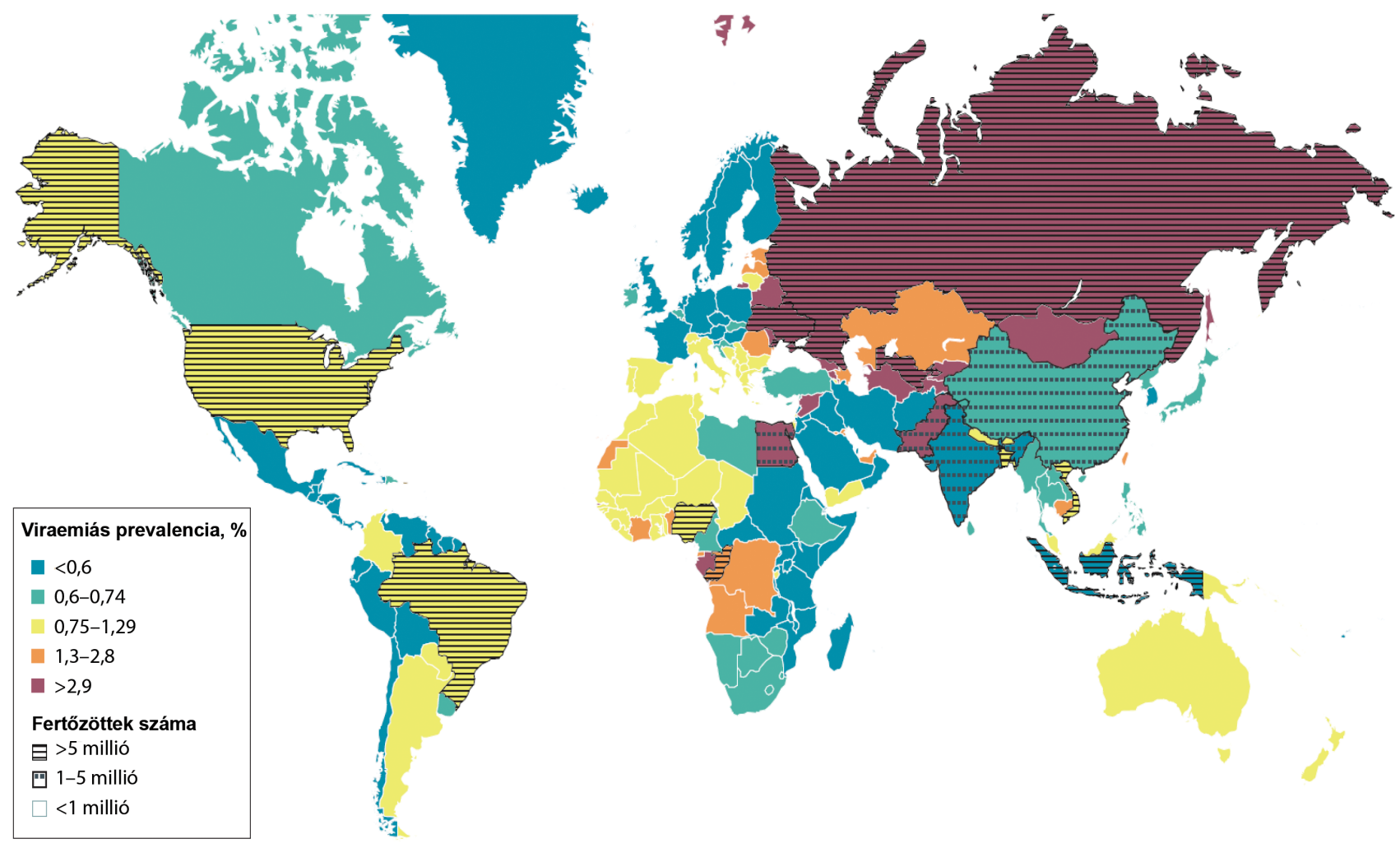

2. ábra | A viraemiás (HCV-RNS-pozitív) infekció globális prevalenciája [16]

sterilizált, többször használatos eszközökkel végzett orvosi és rituális beavatkozások jelentik.

A fiatal, 30 év körüli populáció HCVla-, -3a-, -4- és -6a-fertőződése Nagy-Britanniában, Ausztriában, Luxemburgban, Csehországban és Oroszországban a kábítószer-használattal, míg az idósekben a HCVIb, -2a és -2b elófordulása a korábbi transzfúziókkal és hemodialízissel kapcsolatos. Globálisan 14 millió az iv. kábítószerező, akiknek 67\%-a anti-HCV-pozitív. Ez utóbbi kockázati csoportban évente $26 \%$-os a HCV-fertőződés aránya, míg a reinfekció évi 2\%-5\% (MSM esetén évente 10-15\% a reinfekció valószínúsége) $[15,16,20]$. A HCV-fertőzöttek 30-40\%-ában nem ismert a kockázati tényező.

Az akut C-hepatitis 20-25\%-ban manifesztálódik, 7585\%-ban válik krónikussá, majd 20-30 éven belül 16$20 \%$-ban alakul ki a cirrhosis. A viruseredetü cirrhosis és hepatocellularis carcinoma (HCC) okozta globális halálozás 2013-ban 1454000 volt, a HCV okozta mortalitás pedig $400000 ; 2015$-ben a HCC-halálozás 792000 volt, ennek 25\%-a vezethető vissza $\mathrm{HCV}$-infekcióra [2, 16].

\section{Patogenezis}

\section{Immunológia}

A HCV-fertőzés idültté válásában immunológiai és genetikai tényezők játszanak szerepet. Meghatározó a $C D 8+$ T-sejtek exhaustiója, károsodott proliferációja, az IFN $\gamma$ képzés elégtelensége és a CD4+ helper T-sejt aktivitásának biánya. A T-sejteken a cytotoxicus T-lymphocyta-asszociált antigén-4 (CTLA4), a T-sejt-immunglobulin-mucin(TIM-) és a programozott sejthalál-1 (PDI) inbibitoros „immune checkpoint” receptorok upregulációja, valamint a CD127-es receptor alacsony expressziója észlelhető [18]. A természetes ölő (NK)-sejtek inhibitoros/aktivációs receptorai expresszióját és cytotoxicus aktivitását vizsgálva Szereday és munkatársaival kimutattuk, hogy HCV-infekcióban az NK-sejtek inhibitoros KIR2DL3- és NKG2Creceptor-expressziója fokozott, míg a CD160, NKG2D és KIR3DLI aktivációs receptoroké csökkent [21].

A vírus a kvázispeciesek (escape variánsok) vagy direkt sejt-sejt transzfer révén is elmenekülhet a T-sejt-felismerés elől. HCV hatására a dendritikus sejtekben az IL12képzés csökkenését, az IL10 fokozott képzését is közölték. A HCV-E2-protein és az NK-sejt-CD81 keresztkötése gátolja az NK-funkciót (IFN-képzést, TNF $\alpha$ szekréciót) $[18,22]$.

A HCV direkt hatása, valamint az általa elindított necroinflammatio a cytokinek és az apoptózis révén a hepaticus csillag (stellatum)-sejtek aktiválódásához, fibrogenezishez, cirrhosishoz, DNS-laesiókhoz, sejtproliferációhoz, dysplasiához, végül HCC kialakulásához vezet.

\section{Genetika}

Az adaptív immunválaszban kulcsszerepet játszó $M H C$ II. osztályú molekulák közül a $H L A D Q B{ }^{*} 03$ és a $H L A$ $D R B I^{*} I 1$ társul a HCV spontán clearance-szel [23]. 


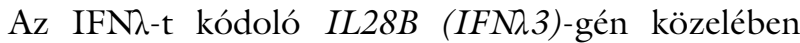
lévő, egy nukleotidot érintő polimorfizmusok (SNP) és a HCV-elimináció kapcsolatát az utóbbi évtizedben fedezték fel: az IL28B SNP rs12979860 CC genotípusa hajlamosít a HCV spontán eliminálására és az IFN-re bekövetkező tartós virológiai válaszra (SVR). Hasonló hatású további IL28B SNP-ket is közöltek, valamint olyan SNP-t is, amely negatívan befolyásolja az SVR-t [18, 22].

Az IL28-gén régiójában az IFN入4-gén olyan variánsát írták le, amelynek a GG-genotípusa magas IFN $\lambda 4$-szinttel és az interferonstimulált gén (ISG) fokozott expressziójával jár. Mindez kedvezőtlen a vírusclearance szempontjából: az IFN $\lambda 4$ az IFN $\lambda$-receptorhoz kötődve az ISG indukcióját okozza, ezáltal a sejt refrakter lesz az IFN $\alpha$ szignálra: a CD8+ T-sejt nem képes IFN $\gamma$-t termelni. Ugyanakkor a csökkent IFN $\lambda 4$-aktivitás (alacsony ISGexpresszióval) fokozott gyulladásos válaszhoz és spontán víruseliminációhoz vezet [24].

A killer sejt immunglobulinszerü receptorok (KIR) az $N K$-sejteken a 19-es kromoszómán lévő gének által kódolt proteinek: aktiválják vagy gátolják az NK-funkciót. A KIR2DLR3-HLAIC kapcsolódás a HCV spontán clearance-ével, a KIR2DS3-HLAC2 kapcsolódás viszont a vírus elégtelen eliminációjával jár [25].

A lipidanyagcserében és a nem alkoholos zsírmáj (NAFLD) patogenezisében szerepet játszó PNPLA3 és TM6SF2 géncsaládok polimorfizmusai C-hepatitisben is hajlamosíthatnak steatosisra, illetve a fibrosis progressziójára [18].

A mikro-RNS-ek (miR) rövid (19-23 nt), nem kódoló RNS-molekulák, a génexpresszió regulátorai. A májspecifikus miR-122 a máj miR-készletének 70\%-át alkotja. A HCV-gén IRES- (internal ribosome entry site) régiójához kötődő miR-122 elősegíti a vírusreplikációt és a virális RNS stabilizációját. A miR-122 gátlása antisense nukleotid antagomiR-rel (Miravirsen ${ }^{\odot}$ ) hatékonyan gátolja a HCV szaporodását [18].

\section{Kórlefolyás}

$\mathrm{Az}$ akut C-hepatitis 15-25\%-a gyógyul spontán, gyermekeknél ez az arány 30-40\%. A több mint 6 hónapnál tovább tartó krónikus C-hepatitis az esetek 70\%-ában progrediál, és 20-30 év alatt 16-20\%-ban cirrhosis alakul ki. A cirrhosis évente 3\%-ban dekompenzálódik, és évi 4-5\% a HCC-incidencia. A HCC kockázata megnő 65 év felett, férfiakban, obesitas, diabetes, HBV- és HIVkoinfekció esetén [2].

A HCV-fertőzés szisztémás betegség [26]. Extrahepaticus manifesztációi részben immunológiai (cryoglobulinaemia, vasculitis, nephritis, arthritis, B-sejt-lymphoma), részben anyagcsere-eredetűek (inzulinrezisztencia, diabetes mellitus), de a direkt patogenitás (fibrotizáló cholestasisos hepatitis), a gyulladásos cytokinek, az oxidatí stressz (cardio- és cerebrovascularis károsodás) és az agysejtekre kifejtett közvetlen hatás (depresszió, kognitív za- varok) is szerepel a mechanizmusok között. Krónikus nephritisben 2,6-22,9\%-os HCV-prevalenciát, HCV-ben a vesebetegség kockázatának megnövekedését (HR: 1,43) írták le [26, 27]. Krónikus vesebetegeket ezért szűrni ajánlott HCV-re, HCV-fertőzötteket pedig vesebetegségre [28]. A HCV extrahepaticus manifesztációinak teljes klinikai spektrumáról Hagymási és mtsai [8] a közelmúltban adtak kitünő áttekintést az Orvosi Hetilapban.

\section{Diagnózis}

\section{Virológia}

- Az anti-HCV-vizsgálat a $H C V$-fertózés kimutatásának első lépcsőjét képviseli, vizsgálata 3. generációs ELISAtechnikával történik. Rapid teszttel, nyálból és száraz cseppből is történhet az antitest detektálása szúrési céllal, pozitivitás esetén kötelező a HCV-RNS-vizsgálat [28]. Akut HCV-expozíció után 2 héten belül jelenik meg a HCV-RNS, és csak 6 héttel később az antitest, amely immundeficiens betegekben hiányozhat. Az anti-HCV évekig megmarad a víruselimináció után is.

- A HCV-RNS kimutatása polimeráz-láncreakcióval (PCR) bizonyíték a viraemiára, s ez alap a kezelés indikálására és a terápia hatásának megítélésére. Akut HCV-infekcióban 12 hét után a HCV-RNS kontrollja szükséges, pozitív esetben terápia indokolt. A krónikus C-hepatitis DAA-kezelése alatt az adherencia követésére az EASL a 2. és a 4 . hét végén is javasolja a HCV-RNS meghatározását, egyébként a víruseliminációt (tartós virológiai válasz, SVR) a kezelés befejezése után 12-24 héttel a negatín HCV-RNS-lelet bizonyítja (SVR12 vagy SVR24) [28].

- A HCV core antigen (p22-protein) is jelzóje a vírusreplikációnak. HCV-RNS helyett, ha az nem áll rendelkezésre, nemcsak szürésre, de terápiás indikációra és az SVR megítélésére is elfogadott. Ez a próba 95\%ban mutatja ki az 500-3000 IU/ml közötti HCV-t $[2,9,10,28]$.

- A HCV-genotípus és -altípus befolyásolja a választandó antivirális szer típusát és a kezelés időtartamát (például GT1 vs. GT3, illetve GTla vs. GT1b) [28]. Gervain és mtsai korábban közölték a hazai GT-megoszlást [29]; újabb adataikat már említettük.

- A rezisztenciaasszociált variánsok (RAV) vizsgálata fóleg a HCVla-genotípusú fertőzés, NS5A (Y93H)mutáció, illetve a DAA-kezelés eredménytelensége esetén szükséges $[6,28]$.

\section{Májbetegség-aktivitás és -stádium}

- A krónikus C-hepatitis hisztológiai aktivitása és fibrosisstádiuma májbiopsziával igazolható [3].

- A kóros GPT jelezheti a gyulladást, de normális lehet a GPT-érték szövettani aktivitás és fibrosis esetén is. 
A GPT-emelkedés $D A A$-kezelés alatt vagy után $H B V$ infekció (reaktiváció!) irányában történó azonnali vizsgálatot indokol [28]. A GOT emelkedése (>1 GOT/ GPT hányados) fibrosisprogresszióra, azaz cirrhosisra (vagy alkoholhatásra) utalhat.

- A fibrosis (F)-stádium meghatározza az alkalmazandó DAA típusát és a kezelés időtartamát. A májbiopszián kívül a fibrosis megítélésére a nem invaziv eljárások, szérummarkerek és -indexek, például GOT/ thrombocyta hányados (APRI score), Fibrosis-4 score (FIB4), Enhanced Liver Fibrosis teszt (ELF) és a különböző elasztográfiák alkalmasak [2, 28]. Az Orvosi Hetilapban erről korábban részletes összefoglalásunk jelent meg [6].

\section{Szürési stratégiák}

Az Egészségügyi Világszervevezet (WHO) által meghirdetett virushepatitis-stratégia (Global health sector strategy on viral hepatitis 2016-2021) célja 90\%-kal csökkenteni az új hepatitisvírus-infekciók számát és $65 \%$-kal a virushepatitis okozta halálozást 2030-ig. Ennek egyik feltétele a nagyszámú, még fel nem fedezett $H C V$-fertözött egyén felkutatása és kezelése a közel 100\%-os hatékonyságú készítményekkel $[9,10]$. Ma a HCV-pozitívak 4585\%-a nem tud a fertözéséröl! Németországban ez az arány $65 \%$, és eddig a kezelést igénylő HCV-fertőzötteknek globálisan < $10 \%$ - $a$ kapott anti-HCV-kezelést [2, 26].

A WHO adatai szerint a feltételezett 71 millió viraemiás HCV-beteg közül 20\% (14 millió) lehet a diagnosztizáltak száma, és 2015-ig összesen 5,4 millió kapott anti-HCV-terápiát. 2015-ben világszerte 1,1 millió HCV-beteget kezeltek (a páciensek felét már DAA-val!), ami a kórismézettek mindössze 7,4\%-ának felelt meg [30].

A WHO az alacsony és közepes gazdagságú országok egészségügyi döntéshozói számára irányelveket dolgozott ki a nemzeti programok elkészítéséhez a hepatitisvírus-szürés és-megelözés módszertanát illetően. A szưrést az adott ország epidemiológiájának, anyagi és személyi feltételeinek figyelembevételével javasolják megtervezni. A cél a szűrést követô kezeléssel megelőzni a fertőzésátvitelt („treatment as prevention” stratégia), másrészt gátolni a májbetegség progresszióját, ezáltal kivédeni a nagy társadalmi terheket jelentő késői szövő́dményeket $[9,10,31]$. A WHO javaslatai a magyar konszenzusajánlásokban is érvényesülnek [32], a hazai nemzeti program előkészítése már 2015-ben megkezdődött [33].

\section{A WHO három szürési stratégiája}

- Célzott (fókuszált) szúrés a kockázati tényezők alapján: kábítószer-használók, homoszexuális férfiak, börtönben elhelyezettek, HIV-, HBV-fertőzöttek, hemodializáltak, hemofíliások, egészségügyi dolgozók tû́szúrásos balesete, HCV-családtagok és -partnerek,
HCV-pozitív anyák újszülöttei, tetováltak, 1990 előtt transzfúziót vagy plazmakészítményt kapott egyének vagy ismeretlen eredetű transzaminázemelkedés esetén.

- Általános populációszúrést a 3-5\% feletti HCV-prevalencia indokolhat. (Japánban „one-off” stratégia: mindenkit életében legalább egyszer szűrnek.) (A várandós anyák szúrését a WHO nem javasolja.)

- Születési dátum szerint (birth cohort): idősek specifikusan azonosított csoportja: bizonyos időperiódusban született populáció szúrése. Példa az Egyesült Államokban az 1945 és 1965 között születettek szúrése: közöttük fordult elő a HCV-fertőzöttek 3/4-e magas, $>3,25-5 \%$-os prevalenciával $[9,10,31]$.

Amig kiterjedt szüröprogramokkal nem sikerül felderiteni a fertözöttek 90\%-át és kezelni a diagnosztizáltak 80\%-át, nem lehet szó a vírushepatitisek globális elimináciojáról [1,2].

A hazai nemzeti program elsóként az egészségügyi dolgozók szűrését tervezi, folytatva más kockázati csoportokkal, és a populációszứrést kockázatfelmérő kérdőívek és szerológiai módszerek kombinációjával [32-34].

\section{Kezelés}

\section{A rekombináns interferontól a szofoszbuvirig}

A HCV-fertőzés gyógyítása a három évtizedes történet külön fejezete - $\mathrm{s}$ ez akkor kezdődött, amikor a vírust még fel sem fedezték. Azt követóen, hogy az 1980-as évek közepére csimpánzkísérletek alapján nyilvánvalóvá vált, hogy a NANB-hepatitist fertőző ágens okozza, Hoofnagle és mtsai 1986-ban 10 krónikus NANB-beteget kezeltek napi $5 \mathrm{ME}$ rekombináns interferonnal (IFN) 12 hónapig. A terápia hatását a GPT és a biopszia alapján ítélték meg, végül 5 betegben lett tartósan normális a GPT [35]. Később az elraktározott szérummintákból igazolható volt a HCV-infekció, majd a HCV-RNS negatívvá válása. Mind az 5 beteg 15-20 év után is élt, májkárosodás nélkül, a nem reagáló betegek közül három később HCC-ben halt meg [1].

Az IFN-nel folytatott randomizált klinikai vizsgálatok után 1991-ben hagyták jóvá a HCV IFN $\alpha 2$ b-kezelését. A virológiai gyógyulás (SVR) aránya a kezdeti 7-11\%-ról fokozatosan emelkedett a guanozinanalóg ribavirin ( $R B V$ ) hozzáadásával, majd a pegilált IFN (peg-IFN) bevezetésével. A peg-IFN + RBV kombináció már közel a betegek felében okozott SVR-t, és egy évtizeden keresztül ez volt a HCV-infekció standard terápiája [1, 2].

A HCV kezelésében a korszakváltás kezdetét a HCV életciklusának felfedezését követôen a direkt ható antivirális szerek (DAA) első képviselői, az NS3/4A-proteázgátlók (a boceprevir és a telaprevir) jelentették. Ezek pegIFN-nel és RBV-vel együtt adva már megkétszerezték az SVR arányát, fő́leg a korábbi, kettős kezelésre nem reagálókban $[2,4]$. 
A teljesen IFN-mentes DAA-terápia 2014-tól az NS5B-gátló szofoszbuvir és az NS5A-gátló ledipaszvir, illetve a paritaprevir/r (NS3/4A-proteázgátló) + ombitaszvir (NS5A-gátló) + daszabuvir (NS5B-gátló) bevezetésével vált lehetővé. Ezek 12-24 hetes időtartamú terápia mellett (RBV-vel vagy a nélkül) a klinikai vizsgálatokban 93-100\%-os SVR-hez vezettek még cirrhosisos betegekben is $[1,2,4]$. Az utóbbi három évben a hazai gyakorlatban is döntően ez a két IFN-mentes DAAkombináció szerepelt, Hunyady és mtsai szerint 912 HCV-beteg kezelése esetén 97\%-os SVR-aránnyal [34].

Jelenleg újabb DAA-k kerülnek forgalomba, amelyekkel vírusgenotípustól, -szubtípustól és betegségstádiumól függően 8-12-24 hét alatt >90-95\%-os SVR érhetó el $[36,37]$; ezeket és a DAA-kezelés irányelveit Horváth és mtsai közleménye [4], valamint a magyar konszenzusajánlás részletesen ismerteti [32].

A 3. ábra a DAA-k három típusát, a gyakorlatban alkalmazott készítményeket és kombinációkat, a 4. ábra az SVR alakulását mutatja az elmúlt 25 év alatt.

A DAA-k 2014. évi bevezetésekor komoly problémát jelentett a gyógyszerek irreálisan magas ára ( 84 000 USD/12 hetes kezelési periódus). Az elmúlt két évben a nemzetközi orvosszakmai társaságok tiltakozásainak, egyes országok egészségügyi hatóságai és a gyógyszergyártók tárgyalásainak, valamint a generikus készítmények megjelenésének köszönhetően már jelentős árcsökkenés következett be. Németországban, Portugáliában, Franciaországban, Egyiptomban minden biztosított HCV-beteg DAA-kezelést kaphat [2]. 2018-tól már Magyarországon is IFN-mentes terápiával kezelhetök még a kevésbé elörehaladott stádiumú fibrosisban szenvedó betegek is.

A DAA-kezelés ma minden viraemiás $H C V$-fertözött számára megfontolandó, ha nincs kontraindikációja. Fontos ellenjavallat, ha nem májbetegséggel kapcsolatos súlyos komorbiditás miatt korlátozott a beteg életkilátása, és nagy az egy éven beliuli elbalálozás valószinüsége [28, 31].

\section{Az SVR (= víruseradikáció) hatásai}

Az SVR a HCV eliminálását jelenti a szervezetből, ami azonban nem egyenlő a májbetegség gyógyulásával. Mégis, az IFN-alapú kezelések kapcsán hosszú távú (810 éves) követések, biopsziával is igazolt vizsgálatok jelezték, hogy az SVR nemcsak a gyulladás megszúnésével, de a fibrosis regressziójával, az extrahepaticus manifesztációk, a HCC-kockázat és a mortalitás csökkenésével is jár $[2,38,39]$. Négy randomizált tanulmányban 3010 előrehaladt fibrosisos HCV-betegben az SVR után 20 hónappal 39-73\%-ban javult a fibrosis, 50\%-ban (F4 alá) regrediált a cirrhosis, és csökkent a portalis hypertensio [40]. Mások szerint HCV-cirrhosisban 7,6 év alatt az új varixképződés SVR után évi $2,1 \%$ vs. 9,1\% volt (nem SVR-betegekben); az SVR a HCC-kockázat 70\%-os és a májjal kapcsolatos halálozás vagy transzplantáció 90\%-os
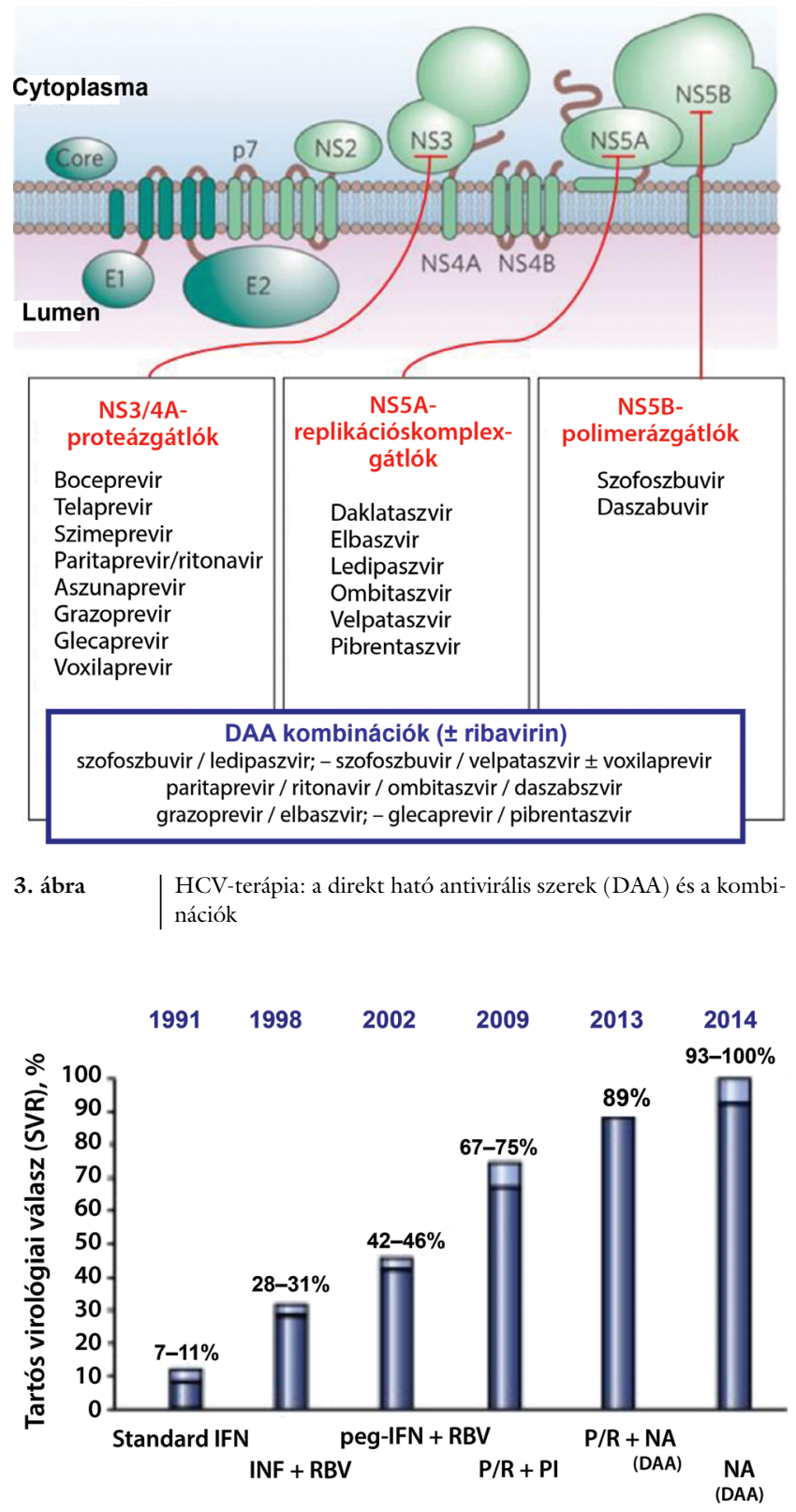

4. ábra $\mid$ Haladás a krónikus C-hepatitis terápiájában: a tartós virológiai válasz (SVR) alakulása [1]

$\mathrm{DAA}=$ direkt ható antivirális szer; IFN = interferon; $\mathrm{NA}=$ nuk leotidanalóg; peg-IFN = pegilált IFN; $\mathrm{PI}=$ proteázgátló; $\mathrm{P} / \mathrm{R}=$ peg-IFN + RBV; RBV= ribavirin

csökkenésével járt [41, 42]. HCV/HIV fertőzöttekben 70,5 hónapos követés alatt a májjal kapcsolatos kumulatív mortalitás $2,9 \%$ volt SVR után, míg 13,9\% az SVR nélküliek között; a cirrhosis miatti halálozás 8 év alatt 94\%-kal csökkent (HR: 0,06) $[38,39]$. Backus és mtsai szerint különböző fibrosisstádiumú HCV-beteg veteránok között az összhalálozás SVR után 10 év alatt 30\%kal csökkent (HR: 0,70); a kumulatív halálozás $9 \%$ vs. $26 \%$ volt (nem SVR esetén) [43]. Cirrhosisban SVR után a HCC évi 4\%-os incidenciája 1\%-ra csökken [38]. A HCV-fertőzés gyógyulásával több mint 4 év minőségi életév (QALY) nyerhető [7]. 
IFN-kezelt HCV-betegekben SVR után az extrahepaticus manifesztációk közül a cryoglobulinaemiás vasculitis 56\%-ban, a B-sejt-lymphoma 75\%-ban regrediált; a diabetes kockázata 6 év alatt 63\%-ot csökkent (HR: $0,24)$, és mérséklődött a HCV-nephritis incidenciája is $[2,27,38]$.

$\mathrm{Az}$ alig több mint 3 éve forgalomba került DAA-kal a hosszú távú követések eredményeire még várni kell. Azonban már az eddigi adatok is jelentősek, azon túlmenően, hogy a „való életben” is közel 90\% az SVR, az IFN + RBV kezelés 35-40\%-os arányával szemben [2, 34]. Nagy különbség, hogy DAA-kombinációkkal olyan betegek is kezelhetók, akik IFN-t nem kaphattak, például dekompenzált cirrhosisban, autoimmun kórképekben vagy depresszióban szenvedők. Ami pedig az életminőséget jelenti, az IFN-alapú terápia maga is rontotta a betegek életminőségét. Ez nem következik be az új szerek esetén, viszont hetek alatt javul a fáradtság, a depresszió, akárcsak a cryoglobulinaemiás vasculitis [38]. Az utóbbi időben előtérbe került vizsgálómódszer, a beteg által megélt és közölt tapasztalatok („patient-reported outcome") regisztrálása is jelezte a DAA-kezelést követő SVR esetén az életminőség, a fizikai funkció, a mentális egészség és a munkaképesség javulását [44].

DAA-kezeléssel elért SVR után egy évvel biopsziával vagy nem invazív eljárásokkal kimutatható volt a fibrosisregresszió. Cirrhosisban a szérumbilirubin, -albumin és -protrombin mellett a MELD score és a Child-Pugh (CP)-stádium változásai tükrözik az SVR kedvező hatását, de jó jel a kórlefolyás alatt a thrombocytaszám emelkedése is [28, 38, 39]. Charlton és mtsai DAA-kezelést követően kimutatták a MELD score javulását [45], mások a cryoglobulinaemia és a B-sejt-lymphoma remisszióját is leírták [46, 47].

Cirrhosisban a fibrosis regressziójával párhuzamos a HCC-kockázat csökkenése, amely azonban sohasem 100\%-os. Dekompenzált cirrhosisban elérhető ugyan DAA-kezelésre 60-80\%-os SVR, egy év után azonban csak a betegek 20\%-ának lesz stabil az állapota [39].

Nincs megállapítva a súlyossági határ („point of no return"), a CP és a MELD score azon értékei, amelyek felett már nem várható eredmény a dekompenzált cirrhosisos beteg DAA-kezelésétől. Mindenesetre 65 éves életkor felett és >20 MELD score esetén ritka a javulás SVR után. Ugyanakkor, ha a DAA hatására a MELD score 15 alá kerül, ez a betegnek a transzplantációs várólistáról való levételét jelenti, ettől kezdve pedig bizonytalan a távlati kórjóslat, mert a beteg állapota újra romolhat. A transzplantáció előtt elért víruselimináció (SVR) megelőzi a mütét után a graft $\mathrm{HCV}$-fertőződését [38, 39, 48].

Az EASL a dekompenzált cirrhosisos betegeket $>18$ 20 MELD score esetén először transzplantálni javasolja és utána kezelni. Ha azonban a listán a várakozási idő több, mint 6 hónap, ezek a betegek is kezelendők [28].

A DAA-terápia klinikai és költséghatékonyságának fokozására nincs eldöntve, hogy a fix dózisú és időtartamú
(8-12 hét) („one size fits all”) terápia vagy az individualizált (válaszfüggő) kezelésmód lenne-e megfelelőbb. Az előbbi egyszerú, könnyen kivitelezhető, de például 12 hét esetén „túlkezeléssel” járhat, míg az utóbbi rövidebb időtartamú, költségkímélőbb lehet, de egyes „nehezen kezelhető” betegekben „alulkezelés” történhet az SVR rovására [49]. Ferenci és mtsai [50] arról számoltak be, hogy $H C V$-cirrhosisos betegek szofoszbuviralapú kezelésekor a 8 hét után HCV-RNS-negatív betegek számára 12 hét kezelés elég volt az SVR-hez, míg a 8 hét után még pozitívak 16-24 hét terápiára gyógyultak.

A DAA-terápiával elért HCV-eradikáció váratlan leleteként írták le spanyol [51] és olasz [52] szerzők, hogy a kuratív sebészi eljárásokkal tumormentessé tett HCCbetegekben az SVR-t követően 3,5, illetve 6 hónapon belül 28-29\%-os gyakorisággal fordult elő a HCC korai kiújulása. Pol és mtsai szerint mindez nem volt megerősíthető [53], ilyen irányban további megfigyelések szükségesek [36].

DAA-kezelés alatt vagy azt követően a $H B V$-infekció aktiválódása, fulmináns $\mathrm{B}$-hepatitis léphet fel. Ezért fontos a DAA-terápia elótt a beteg $\mathrm{HBV}$-státuszának tisztázása és a HBsAg- (és HBV-DNS-) pozitív betegek antivirális nukleotidanalóg kezelése, vagy izolált antiHBc-pozitivitás esetén a GPT-szint monitorozása [28]. Itt említendő meg, hogy a HAV- és HBV-vakcináció minden krónikus májbeteg számára indokolt, ez HCVfertőzöttek esetén különösen ajánlott [28].

\section{Gondozás, követés SVR után}

A kockázati tényezők és a májbetegség stádiuma határozza meg az SVR utáni időszakban a vírusmentessé tett egyének gondozásának módját.

A különösen nagy kockázatú populációk (kábítószerezők, börtönben elhelyezettek, MSM) gondozásában fontos a pszichés vezetés és annak tudatosítása, hogy a DAA-kezeléssel elért vírusmentesség (SVR) nem véd meg az újrafertôzéstől (évi 5-15\%). A kockázati magatartásnál ezt figyelembe kell venni. E téren fontos az edukáció, hasznosak a tücsere-, illetve opiátszubsztitúciós programok, MSM esetén pedig évente HCV-RNS-kontrollt javasolnak [28, 31].

A májbetegekben SVR után a fibrosisstádium és a komorbiditás határozza meg a tennivalókat. Az EASL a DAA-terápia befejezését követő 48 hét múlva az SVR megerösítését javasolja [28]. F0-Fl-betegek követése az alapellátásban folytatható, ha nincs komorbiditás. F2-es fibrosis esetén progresszió irányában néhány évig további szakorvosi ellenőrzés szükséges, különösen, ha kockázati tényezők is vannak. Az F3/F4-es stádium 6 havonta hasi ultrahang (UH)- és 1-2 évente varixvizsgálatot indokol [28].

Bármelyik stádiumban fontos a fibrosisprogressziót okozó tényező́k kiküszöbölése, így az alkoholtilalom mellett az NAFLD, az obesitas, a diabetes, a HBV- és a HIV-infekció kezelése [28, 31]. 


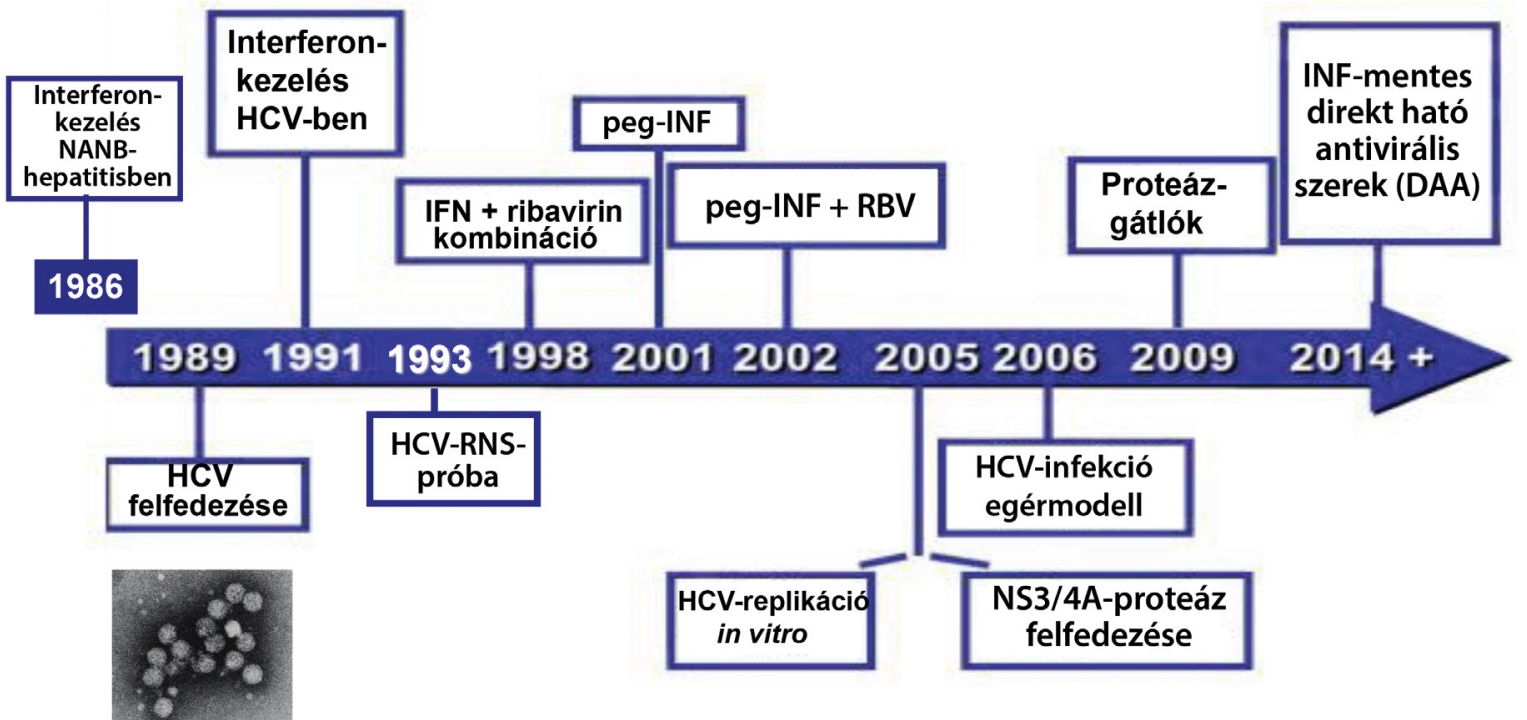

5. ábra

Mérföldkövek a HCV történetében: a transzlációs kutatás sikere (Módosítva Szabó Gy. 2014. AASLD - American Association for the Study of Liver
Disease - után)
IFN = interferon; NANB = non-A, non-B

Az 5. ábra a HCV-kutatás történetének mérföldköveit foglalja össze.

\section{Feladatok a jövőben}

- A WHO irányelvei és a nemzeti programok alapján folytatni a szürőprogramokat, felderíteni, majd kezelni minden HCV-fertőzöttet („kezelés mint prevenció stratégia”).

- Megelőzni a vírusmentessé tett személyek újrafertőződését, mind az egészségügyi ellátók, mind az érintettek edukációja és a kockázatcsökkentő eljárások révén.

- Biztosítani a pángenotípus-hatású, rövid időtartamú kezeléssel járó DAA-készítményekhez való széles körü hozzáférést, beleértve az árak csökkentését is.

- Megoldani a nehezen kezelhető populációk, a DAA-ra nem reagáló, a RAV-mutánsok vagy a 3-as genotípussal (GT3) fertőzöttek terápiáját.

- Folytatni a HCV-vakcina-kutatást, annak tudatában, hogy vakcina nélkül kérdéses lehet a HCV globális eradikációja [1, 2, 37].

Anyagi támogatás: A közlemény megírása anyagi támogatásban nem részesült.

Szerzői munkamegoszlás: A dolgozat a két szerző közös munkája. A cikk végleges változatát mindkét szerző elolvasta és jóváhagyta.

Érdekeltségek: A szerzők előadói/tanácsadói díjban részesültek az alábbi gyógyszer előállítóktól/forgalmazóktól: AbbVie Kft., BMS, Fresenius-Kabi, Gilead Sciences.

\section{Irodalom}

[1] Pawlotski JM, Feld JJ, Zeuzem S, et al. From non-A, non-B hepatitis to hepatitis C virus care. J Hepatol. 2015; 62(1 Suppl): S87-S99.

[2] Manns MP, Buti M, Gane E, et al. Hepatitis C virus infection. Nat Rev Disease Primers 2017; 3: 17006.

[3] Schaff Zs, Gógl Á, Dóra R, et al. The pathology of hepatitis C. [A hepatitis C patológiája.] Orv Hetil. 2015; 156: 836-839. [Hungarian]

[4] Horváth G, Halász T, Makara M, et al. New era in the treatment of chronic hepatitis $\mathrm{C}$ - novel direct acting antivirals. [Korszakváltás a krónikus C-vírus hepatitis terápiájában - az új direkt ható antivirális szerek.] Orv Hetil. 2015; 156: 841-848. [Hungarian]

[5] Tornai I. Significance of hepatitis C virus baseline polymorphism during the antiviral therapy. [A hepatitis C-vírus-bázispolimorfizmus jelentősége a kezelésben.] Orv Hetil. 2015; 156: 849-854. [Hungarian]

[6] Pár A, Vincze Á, Pár G. Non-invasive diagnostic methods of fibrosis in chronic hepatitis $\mathrm{C}$ virus infection: their role in the treatment indication, follow-up and assessment of prognosis. [Nem invazív fibrosisdiagnosztika hepatitis C-vírus-infekcióban: szerepe a kezelés indikációjában, követésében és a prognózis megítélésében.] Orv Hetil. 2015; 156: 855-861. [Hungarian]

[7] Makara M, Hunyady B. Financial burden of hepatitis C infection and its treatment. [A hepatitis C-vírus-fertőzés és kezelésének költségvonzata.] Orv Hetil. 2015; 156: 862-868. [Hungarian]

[8] Hagymási K, Egresi A, Lengyel G. Extrahepatic manifestations in chronic hepatitis $\mathrm{C}$ infected patients. [Extrahepaticus manifesztációk idült hepatitits C-vírus-fertőzöttekben.] Orv Hetil. 2017; 158: 603-611. [Hungarian]

[9] World Health Organization. Global health sector strategy on viral hepatitis 2016-2021. Towards ending viral hepatitis. WHO, Geneva, June 2016. Available from: http://apps.who.int/iris/ bitstream/10665/246177/1/WHO-HIV-2016.06-eng. pdf?ua $=1$

[10] World Health Organization. Guidelines for the screening, care and treatment of persons with chronic hepatitis $\mathrm{C}$ infection. Updated version. WHO, Geneva, April 2016. Available from: 
http://apps.who.int/iris/bitstream/10665/205035/l/ 9789241549615_eng.pdf?ua $=1$

[11] Feinstone SM, Kapikian AZ, Purcell RH, et al. Transfusion-associated hepatitis not due to viral hepatitis type A or B. N Engl J Med. 1975; 292: 767-770.

[12] Alter HJ, Purcell RH, Holland PV, et al. Transmissible agent in non-A, non-B hepatitis. Lancet 1978; 1(8062): 459-463.

[13] Schaff Z, Tabor E, Jackson DR, et al. Ultrastructural alterations in serial liver biopsy specimens from chimpanzees experimentally infected with a human non-A, non-B hepatitis agent. Virhows Arch B Cell Pathol Inc Mol Pathol. 1984; 45: 301-312.

[14] Choo QL, Kuo G, Weiner AJ, et al. Isolation of a cDNA clone derived from a blood-borne non-A, non-B viral hepatitis genome. Science 1989; 244: 359-362.

[15] Bukh J. The history of hepatitis C virus (HCV): Basic research reveals unique features in phylogeny, evolution and the viral life cycle with new perspectives for epidemic control. J Hepatol. 2016; 65(S1): S2-S21.

[16] The Polaris Observatory HCV Collaborators. Global prevalence and genotype distribution of hepatitis $\mathrm{C}$ virus infection in 2015: a modelling study. Lancet Gastroenterol Hepatol. 2017; 2: 161176.

[17] Barba G, Harper F, Harada, T, et al. Hepatitis C virus core protein shows a cytoplasmic localization and associates to cellular lipid storage droplets. Proc Natl Acad Sci USA 1997; 94: 12001205.

[18] Heim MH, Bochud PY, George J. Host - hepatitis C viral interactions: The role of genetics. J Hepatol. 2016; 65(1 Suppl): S22-S32.

[19] Barna TK, Ozsvár Z, Szendrényi V, et al. Hepatitis C virus antibody in the serum of blood donors. [Hepatitis C-vírus ellenanyag előfordulása véradók szérumában.] Orv Hetil. 1996; 137: 507-511. [Hungarian]

[20] Midgard H, Weir A, Palamateer N, et al. HCV epidemiology in high risk groups and the risk of reinfection. J Hepatol. 2016; 65(1 Suppl): S33-S45.

[21] Szereday L, Meggyes M, Halász M, et al. Immunological changes in different patient populations with chronic hepatitis $\mathrm{C}$ virus infection. World J Gastroenterol. 2016; 22: 4848-4859.

[22] Pár A, Pár G. Immune response and oxidative stress in hepatitis $\mathrm{C}$ virus infection. [Immunválasz és oxidatív stressz hepatitis Cvírus-infekcióban.] Orv Hetil. 2015; 156: 1898-1903. [Hungarian]

[23] Miki D, Ochi H, Takahashi, A, et al. HLA-DQB1*03 confers susceptibility to chronic hepatitis $\mathrm{C}$ virus in Japaneses: a genomwide association study. PLoS ONE 2013; 8: e84226.

[24] Terczy ska-Dyla E, Bibert S, Duong FH, et al. Reduced IFN $\lambda 4$ activity is associated with improved HCV clearance and reduced expression of interferon-stimulated genes. Nat Commun. 2014; 5: 5699

[25] Dring MM, Morrison MH, McSharry BP, et al. Innate immune genes synergize to predict increased risk of chronic disease in hepatitis C virus infection. Proc Natl Acad Sci USA 2011; 108: 5736-5741

[26] Younossi ZM, Birerdinc A, Henry L. Hepatitis C infection: A multi-faceted systemic disease with clinical, patient reported and economic consequences. J Hepatol. 2016; 65(1 Suppl): S109-S119.

[27] Cacoub P, Desbois AC, Isnard-Bagnis C, et al. Hepatitis C virus infection and chronic kidney disease. Time for reappraisal. J Hepatol. 2016; 65(1 Suppl): S82-S94.

[28] European Association for the Study of the Liver. EASL recommendations on treatment of hepatitis C 2016. J Hepatol. 2017; 66: 153-194.

[29] Gervain J, Simon G Jr, Papp I, et al. Analysing the type and subtype of hepatitis virus $\mathrm{C}$ of chronic viral hepatitis patients in Hungary. [A magyarországi krónikus $\mathrm{C}$ vírushepatitises betegek vírustípus- és szubtípus-meghatározása.] Orv. Hetil. 2001; 142: 1315-1319. [Hungarian]
[30] World Health Organization. Hepatitis C. Fact sheet - Updated October 2017. Available from: http://www.who.int/mediacentre/factsheets/fs164/en/

[31] Easterbrook PJ, on behalf of the WHO Guidelines Development Group. Who to test and how to test for chronic hepatitis $\mathrm{C}$ infection - 2016 WHO testing guidance for low- and middle-income countries. J Hepatol. 2016; 65(1 Suppl): S46-S66.

[32] Hunyady B, Gerlei Z, Gervain J, et al. Screening, diagnosis, treatment, and follow up of hepatitis $\mathrm{C}$ virus related liver disease. National consensus guideline in Hungary from 22 September 2017. [A hepatitis C-vírus-fertőzés szúrése, diagnosztikája, antivirális terápiája, kezelés utáni gondozása. Magyar konszenzusajánlás. Érvényes 2017. szeptember 22-től.] Orv Hetil. 2018; 159(Suppl 1): 3-23. [Hungarian]

[33] Hunyady B, Gervain J, Gógl Á, et al. National strategy to prepare eradication of hepatitis $\mathrm{C}$ virus infection in Hungary. [Nemzeti program a hepatitis C-vírus-fertőzés magyarországi felszámolásának előkészítésére.] Medical Online 2015. november 06. Available from: http://www.medicalonline.hu/cikk/nemzeti_ program_a_hepatitis_c_virus_fertozes_magyaror-szagi_felszamolasanak_elokeszitesere [Hungarian]

[34] Hunyady B, Horváth G, Makara M. Present status and perspectives of patients with chronic hepatitis $\mathrm{C}$ in Hungary. [A krónikus virushepatitiszes betegek helyzete és perspektivái Magyarországon.] Orvostovábbképző Szle. 2017; 24: 33-38. [Hungarian]

[35] Hoofnagle JH, Mullen KD, Jones DB, et al. Treatment of chronic non-A, non-B hepatitis with recombinant human alfa interferon. A preliminary report. N Engl J Med. 1986; 315: 15751578 .

[36] Feld JJ, Foster GR. Second generation direct-acting antivirals Do we expect major improvements? J Hepatol. 2016; 65 (1 Suppl): S130-S142.

[37] Moradpour D, Grakoui A, Manns MP. Future landscape of hepatitis $\mathrm{C}$ research - basic, translational and clinical perspectives. J Hepatol. 2016; 65(1 Suppl): S143-S155.

[38] van der Meer AJ, Berenguer M. Reversion of disease manifestations after HCV eradication. J Hepatol. 2016; 65 (1 Suppl): S95S108.

[39] Terrault NA, Hassanein TI. Management of the patient with SVR. J Hepatol. 2016; 65(1 Suppl): S120-S129.

[40] Poynard T, McHutchison J, Manns M, et al. Impact of pegylated interferon alfa- $2 \mathrm{~b}$ and ribavirin on liver fibrosis in patients with chronic hepatitis C. Gastroenterology 2002; 122: 1303-1313.

[41] Morgan RL, Baack B, Schmith BD, et al. Eradication of hepatitis $\mathrm{C}$ virus infection and the development of hepatocellular carcinoma: a meta-analysis of observational studies. Ann Intern Med. 2013; 158: 329-337.

[42] Veldt BJ, Heathcote EJ, Wedemeyer H, et al. Sustained virological response and clinical outcomes in patients with chronic hepatitis C and advanced fibrosis. Ann Intern Med. 2007; 147: 677684.

[43] Backus LI, Boothroyd DB, Philips BR, et al. A sustained virological response reduces risk of all-cause mortality in patients with hepatitis C. Clin Gastroenterol Hepatol. 2011; 9: 509-516.

[44] Younossi ZM, Stepanova M, Feld J, et al. Sofosbuvir and velpatasvir combination improves patient-related outcomes for patients with hepatitis $\mathrm{C}$ virus infection without or with compensated or decompensated cirrhosis. Clin Gastroenterol Hepatol. 2017; 15: 421-430.e6

[45] Charlton M, Everson GT, Flamm SL. Ledipasvir and sofosbuvir plus ribavirin for treatment of hepatitis $\mathrm{C}$ virus infection in patients with advanced liver disease. Gastroenterology 2015; 149 : 649-659.

[46] Saadoun D, Pol S, Ferfar Y, et al. Efficacy and safety of sofosbuvir plus daclatasvir for treatment of HCV-associated cryoglobulinaemia vasculitis. Gastroenterology 2017; 153: 49-52.e5.

[47] Arcaini L, Besson C, Frigeni M, et al. Interferon-free antiviral treatment in B-cell lymphoproliferative disorders associated with hepatitis C virus infection. Blood 2016; 128: 2527-2532. 
[48] Belli LS, Berenguer M, Cortesi PA, et al. Delisting of liver transplant candidates with chronic hepatitis $\mathrm{C}$ after viral eradication: a European study. J Hepatol. 2016; 65: 524-531.

[49] Maasoumy B, Vermehren J. Diagnostics in hepatitis C: The end of response-guided therapy? J Hepatol. 2016; 65(1 Suppl): S67S81.

[50] Ferenci P, Kozbial K, Mandorfer M, et al. HCV targeting of patients with cirrhosis. J Hepatol. 2015, 63: 1015-1022.

[51] Reig M, Mariño Z, Perelló C, et al. Unexpected high rate of early tumor recurrence in patients with HCV-related HCC undergoing interferon-free therapy. J Hepatol. 2016; 65: 719-726.
[52] Conti F, Buonfiglioli F, Scuteri A, et al. Early occurrence and recurrence of hepatocellular carcinoma in HCV-related cirrhosis treated with direct acting antivirals. J Hepatol. 2016; 65: 727733.

[53] Pol S. Lack of evidence of an effect of direct-acting antivirals on the recurrence of hepatocellular carcinoma: Data from three ANRS cohorts. J Hepatol. 2016; 65: 734-740.

(Pár Alajos dr., Pécs, Ifjúság u. 13., 7624 e-mail: par.alajos@pte.hu)

\section{MEGHÍVÓ}

Ünnepi Tudományos Ülés és szoborcsoport avatás Semmelweis Ignác születésének 200. évfordulója tiszteletére - Tisztelgés Semmelweis Ignác előtt 200. születésnapja alkalmából a Semmelweis Egyetem szülész "honoris causa” díszdoktorainak részvételével

Időpont: 2018. június 30. (szombat), 10:00-15:00

Helyszín: Semmelweis Egyetem Nagyvárad téri Elméleti Tömb, Díszterem

Szervező elnökök: Prof. Dr. Papp Zoltán és Prof. Dr. Rosivall László

Rendezők: Semmelweis Egyetem, Orvosi Hetilap, Semmelweis Kiadó, Professional Publishers,

Akadémiai Kiadó Zrt., lan Donald Inter-University School (a Magyar Tagozat 15. rendezvénye),

Medicina Könyvkiadó Zrt. és a magyar szülészorvos társadalom (Magyar Nóorvosok Társasága)

Házigazda: A Semmelweis Egyetem és a Maternity Szülészeti és Nőgyógyászati Magánklinika, Budapest

\section{PROGRAM}

A transformative icon for modern perinatology

Üléselnökök: Prof. Dr. Szél Ágoston, a Semmelweis Egyetem rekłora, Prof. Dr. Merkely Béla, a Semmelweis Egyetem rekłorjelöltje és

Prof. Dr. Bódis József, a Pécsi Tudományegyetem rektora, a Magyar Nőorvos Társaság elnöke

10:00 - 13:20

Prof. Dr. Rosivall László (Budapest):

Semmelweis, aki felfedezte a kórt, de nem győzte meg a kort

Prof. Dr. Dr. h.c. Frank A. Chervenak (New York):

Ethical dimensions of puerperal sepsis 170 years ago and today

Prof. Dr. Gazda István (Budapest):

Semmelweis Ignác az orvostörténész szemszögéből

Prof. Dr. Dr. h.c. Roberto Romero (Detroit):

New challenges of maternal and fetal infections in the $21^{\text {st }}$ century

Prof. Dr. Kiss László (Csilizradvány):

Semmelweis Ignác és az Orvosi Hetilap

Prof. Dr. Dr. h.c. Asim Kurjak (Zagreb):

The role of ultrasound in prevention and management of perinatal sepsis

Prof. Dr. Papp Zoltán (Budapest): Semmelweis Ignác késői tanszéki utódjának megemlékezése

Prof. Dr. Didier Pittet (Geneva):

Following Semmelweis

13:20-13:45

Séta a Semmelweis Egyetem Külső Klinikai Tömbjéhez

(az egyetem II. Sz. Szülészeti és Nőgyógyászati Klinikójához)

13:45-14:00

Semmelweis emlékére Madarassy István mưvész által készített

"Aldott állapotban - Vizitáció Semmelweis emlékére" címư szoborcsoport leleplezése

14:00-15:00

Fogadás a Külső Klinikai Tömbben

Az Orvosi Hetilap (Semmelweis születésnapi emlékszám, 159. évfolyam 26. szám, 2018. július 1.) közölni fogja a négy magyar nyelvư, a Nőgyógyászati és Szülészeti Továbbképző Szemle (20. évfolyam 3. füzet, 2018. június) pedig a három "honoris causa" díszdoktor angol nyelvü előadását. (Mindkét lap fôszzerkesztője Prof. Dr. Papp Zoltán.) A résztvevők mindkét füzetet ajándékként kapják.

Egyidejűleg a helyszínen kedvezményesen megvásárolható a Rosivall László szerkesztésében megjelenô Semmelweis Emlékkötet magyar és angol nyelvư változata (Semmelweis Kiadó, Budapest, 2018) és a Papp Zoltán által szerkesztett Szülészet-Nógyógyászat Trilógia kötetei (,A várandósgondozás kézikönyve”, 2016, „A perinatológia kézikönyve. Második kiadás”, 2018 és „A nőgyógyászat kézikönyve”, 2016, Medicina Könyvkiadó Zrt., Budapest), továbbá a Semmelweis Kiadó legújabb könyve, a Papp Zoltán által írt „A szülészet-nógyógyászat tankönyve. Ötödik kiadás”, 2017 kötet.

Részvételi dij nincs, elôzetes regisztráció szükséges a www.semmelweis.hu honlap eseménynaptárában az adott napi programnál 